\title{
Freshwater oligochaetes of India: A review
}

\author{
H. S. Singh*, Richa Agrawal and Anshu Chaudhary \\ Department of Zoology, Ch. C. S. University, Meerut- 250004 (U.P.), INDIA \\ *Corresponding author. E-mail:hirdaya_singh@ @rediffmail.com
}

Abstract: The present review deals with freshwater oligochaetes of India which records the presence of 102 species of freshwater oligochaetes belonging to 17 genera and 4 families. Besides this, a brief description of their global and Indian distribution has also been made along with their ecology, morphology of typical oligochaetes methods of their collection and preparation for taxonomic study has also been given. A thorough survey of various states is needed for the distribution of oligochaetes systematically

Keywords : Oligochaetes, Aeolosomatidae, Naididae, Tubificidae, Pristinidae

\section{INTRODUCTION}

Correct identification of Oligochaetes is imperative to any bioassessment project. Oligochaetes generally comprise of $50 \%$ of the macro invertebrate communities in Indian lakes, rivers and streams, at least $10 \%$ of the benthic community in estuaries near shore, coastal areas etc. and $40 \%$ are terrestrial (Fig. 1). Both freshwater and marine oligochaetes form an integer component of aquatic communities throughout the world. This group largely contributes to diet of bottom feeding omnivores. Many environmental studies have focused on the use of freshwater oligochaetes as indicator of trophic condition. Stephenson (1930) authored one of the major reviews of oligochaeta, but this was primarily as an overview of the Zoology of this group not as taxonomic reference. Subsequently, Sperber (1948) published the most comprehensive contribution to the taxonomy of Naididae not until Brinkhurst and Jamieson (1971) compiled a voluminous information of systematic and taxonomy of aquatic oligochaetes of the world. Brinkhurst and Wetzal published the supplement to 1984 , the global review provided an annotated list of freshwater oligochaetes described or revised oligochaetes of 1971 to 1972 . Shortly after Brinkhurst (1986) again published the guide of freshwater oligochaetes of the world as a supplement to previous contribution.

After the above mentioned major contribution there was complete silence. However, sporadic references used to appear from different corners of the world including India. Freshwater oligochaetes besides being biotic component of environment and constituting diet of bottom dwelling animals, they use to act as intermediate host of Myxosporians which causes a serious parasitic problem for the freshwater fishes. Thus, the thorough investigation of this group in Indian water warrants serious attention.

\section{FRESHWATER INDIAN OLIGOCHAETES}

Study of the taxonomy of freshwater oligochaetes is sporadic and unsystematic. Some of the important workers like Naidu, Dhillon, Rani, Kapoor, Sharma and Battish have made some studies in different states of India. The investigator collected the literature and prepared a checklist of freshwater oligochaetes reported from India. This checklist shows that in all Kashmir, Andhra Pradesh, Punjab, West Bengal, Uttar Pradesh, Maharashtra, Karnataka, Kerala and TamilNadu are the states so far been explored (Fig.2.) that too very unsystematically. The unexplored states are Himachal Pradesh, Uttaranchal, Delhi, Haryana, Rajasthan, Gujarat, Madhya Pradesh, Bihar, Chhattisgarh, Orrisa, Jharkhand, Arunachal Pradesh, Sikkim, Assam, Manipur, Nagaland, Meghalaya, Tripura, Mizoram and Goa. The Indian freshwater oligochaete fauna is represented by 17 genera in four different families viz.,Aeolosomatidae, Naididae, Tubificidae, Pristinidae.

\section{DISTRIBUTION}

Genus Aeolosoma was first of all reported by Ehrenberg (1828). This genus is reported in Europe, Asia, Africa, North and South America but has yet not been reported from Australia. In Indian sub-continent, it is reported from Ceylon, Cuddapah, Bellary, Kakinada, Lahore and Kashmir. Genus Aulophorus was first reported by Schmarda (1861). This genus is distributed in Europe, Asia, Africa, Australia, North and South America. In Indian subcontinent, it is distributed in Ceylon, Trivandrum, Ouralpatti, Tandikondi, Madras, Cuddapah, Bellary, 
Table 1. A checklist of freshwater Oligochaetes of India.

\begin{tabular}{|c|c|c|c|}
\hline S.No. & Name & Author & Locality \\
\hline 1. & Aeolosoma hyalinum & Naidu et.al.,(1979) & Andhra Pradesh (Vizianagaram) \\
\hline 2. & A. hemprichi & Dhillon and Kaur (1991-96) & Ferozepur \\
\hline 3. & A. vindae & Rani (1975) & Ludhiana \\
\hline 4. & A. bengalense & Naidu(1966) & Tibet \\
\hline 5. & A. hemprichii & Naidu and Naidu (1979) & Kashmir \\
\hline 6. & A. hemprichii & Naidu(1966) & Tibet \\
\hline 7. & A. kashyapi & Naidu(1966) & Tibet \\
\hline 8. & A. ternarium & Naidu(1966) & Tibet \\
\hline 9. & A. travancorense & Naidu(1966) & Tibet \\
\hline 10. & Aulophorus flabelliger & Kalpana and Naidu (1979) & Andhra Pradesh (Vizianagaram) \\
\hline 11. & A. furcatus & Naidu et.al.,(1979) & AndhraPradesh (Vizianagaram) \\
\hline 12. & A. hymanae & Naidu et.al.,(1979) & Andhra Pradesh (Vizianagaram) \\
\hline 13. & A. furcatus & Naidu and Naidu (1979) & Kashmir \\
\hline 14. & A. furcatus & Naidu(1966) & Tibet \\
\hline 15. & A. gravelyi & Naidu(1966) & Tibet \\
\hline 16. & A. hymanae & Naidu(1966) & Tibet \\
\hline 17. & A. indicus & Naidu(1966) & Tibet \\
\hline 18. & A. michaelseni & Naidu(1966) & Tibet \\
\hline 19. & A. moghei & Naidu(1966) & Tibet \\
\hline 20. & A. tonkinensis & Naidu(1966) & Tibet \\
\hline 21. & Nais communis & Naidu et.al.,(1979) & Andhra Pradesh (Vizianagaram) \\
\hline 22. & N. communis & Rani (1975) & Ludhiana \\
\hline 23. & N. communis punjabensis & Naidu and Naidu (1979) & Kashmir \\
\hline 24. & N. communis caeca & Naidu and Naidu (1979) & Kashmir \\
\hline 25. & N. variabilis punjabensis & Naidu and Naidu (1979) & Kashmir \\
\hline 26. & N. furcatus & Naidu and Naidu (1979) & Kashmir \\
\hline 27. & N. variabilis & Naidu and Naidu (1979) & Kashmir \\
\hline 28. & $N$. andina & Naidu(1966) & Tibet \\
\hline 29. & N. barbata & Naidu(1966) & Tibet \\
\hline 30. & N. communis & Naidu(1966) & Tibet \\
\hline 31. & N. communis caeca & Naidu(1966) & Tibet \\
\hline 32. & N. communis punjabensis & Naidu(1966) & Tibet \\
\hline 33. & N. elinguis & Naidu(1966) & Tibet \\
\hline 34. & N. gwaliorensis & Naidu(1966) & Tibet \\
\hline 35. & N. menoni & Naidu(1966) & Tibet \\
\hline 36. & N. obtuse & Naidu(1966) & Tibet \\
\hline 37. & N. paraguayensis & Naidu(1966) & Tibet \\
\hline 38. & N. paraguayensis aequalis & Naidu(1966) & Tibet \\
\hline 39. & N. pectinata & Naidu(1966) & Tibet \\
\hline
\end{tabular}


Table 1 contd....

\begin{tabular}{|c|c|c|c|}
\hline 40. & N. raviensis & Naidu(1966) & Tibet \\
\hline 41. & N. variabilis & Naidu(1966) & Tibet \\
\hline 42. & N. communis & Naidu and Naidu (1979) & Nilgiris (South India) \\
\hline 43. & $N$. andhrensis & Naidu and Naidu (1979) & Nilgiris (South India) \\
\hline 44. & N. menoni & Naidu and Naidu (1979) & Nilgiris (South India) \\
\hline 45. & Dero digitata & Naidu et.al., (1979) & Andhra Pradesh (Vizianagaram) \\
\hline 46. & D. cooperi & Naidu et.al., (1979) & Andhra Pradesh (Vizianagaram) \\
\hline 47. & D. indica & Naidu et.al., (1979) & Andhra Pradesh (Vizianagaram) \\
\hline 48. & D. obtuse & Naidu et.al., (1979) & Andhra Pradesh (Vizianagaram) \\
\hline 49. & D. nivea & Naidu et.al., (1979) & Andhra Pradesh (Vizianagaram) \\
\hline 50. & D. cooperi & Sharma (1993) & Ludhiana \\
\hline 51. & D. indica & Sharma (1993) & River Ghaggar \\
\hline 52. & D. limosa & Rani (1975) & Ludhiana \\
\hline 53. & D. zeylanica & Rani (1975) & Ludhiana \\
\hline 54. & D. furcatus & Naidu and Naidu (1979) & Kashmir \\
\hline 55. & D. austrina & Naidu(1966) & Tibet \\
\hline 56. & D. cooperi & Naidu(1966) & Tibet \\
\hline 57. & D. digitata & Naidu(1966) & Tibet \\
\hline 58. & D. dorsalis & Naidu(1966) & Tibet \\
\hline 59. & D. indica & Naidu(1966) & Tibet \\
\hline 60. & D. limosa & Naidu(1966) & Tibet \\
\hline 61. & D. nivea & Naidu(1966) & Tibet \\
\hline 62. & D. palmate & Naidu(1966) & Tibet \\
\hline 63. & D. pectinata & Naidu(1966) & Tibet \\
\hline 64. & D. plumose & Naidu(1966) & Tibet \\
\hline 65. & D. sawayai & Naidu(1966) & Tibet \\
\hline 66. & D. zeylanica & Naidu(1966) & Tibet \\
\hline 67. & Allonais gwaliorensis & Naidu et.al.,(1979) & Andhra Pradesh (Vizianagaram) \\
\hline 68. & A. rayalaseemensis & Naidu et.al.,(1979) & Andhra Pradesh (Vizianagaram) \\
\hline 69. & A. gwaliorensis & Naidu(1966) & Tibet \\
\hline 70. & A. inaequalis & Naidu(1966) & Tibet \\
\hline 71. & A. paraguayensis & Naidu(1966) & Tibet \\
\hline 72. & A. pectinata & Naidu(1966) & Tibet \\
\hline 73. & A. rayalaseemensis & Naidu(1966) & Tibet \\
\hline 74. & Pristina aequiseta & Naidu et.al.,(1979) & Andhra Pradesh (Vizianagaram) \\
\hline 75. & P. longiseta longiseta & Naidu et.al.,(1979) & Andhra Pradesh (Vizianagaram) \\
\hline 76. & P. longiseta longiseta & Naidu and Naidu (1979) & Kashmir \\
\hline 77. & P. evelinae & Naidu(1966) & Tibet \\
\hline 78. & P. foreli & Naidu(1966) & Tibet \\
\hline 79. & P. jenkinae & Naidu(1966) & Tibet \\
\hline 80. & $P$. longiseta & Naidu(1966) & Tibet \\
\hline
\end{tabular}


Table 1 contd....

\begin{tabular}{|c|c|c|c|}
\hline 81. & P. menoni & Naidu(1966) & Tibet \\
\hline 82. & P. minuta & Naidu(1966) & Tibet \\
\hline 83. & P. proboscidea & Naidu(1966) & Tibet \\
\hline 84. & P. sperberae & Naidu(1966) & Tibet \\
\hline 85. & P. synclites & Naidu(1966) & Tibet \\
\hline 86. & P. aequiseta & Naidu and Naidu (1979) & Nilgiris (South India) \\
\hline 87. & P. longiseta longiseta & Naidu and Naidu (1979) & Nilgiris (South India) \\
\hline 88. & Branchiodrilus semperi & Sharma (1993) & Ludhiana \\
\hline 89. & B. hortensis & Naidu(1966) & Tibet \\
\hline 90. & B. menoni & Naidu(1966) & Tibet \\
\hline 91. & B. semperi & Naidu(1966) & Tibet \\
\hline 92. & Chaetogaster sp. & Dhillon and Kaur (1991-96) & Ferozepur \\
\hline 93. & C. annandalei & Naidu(1966) & Tibet \\
\hline 94. & C. bengalensis & Naidu(1966) & Tibet \\
\hline 95. & C. cristallinus & Naidu(1966) & Tibet \\
\hline 96. & C. diaphanus & Naidu(1966) & Tibet \\
\hline 97. & C. diastrophus & Naidu(1966) & Tibet \\
\hline 98. & C. langi & Naidu(1966) & Tibet \\
\hline 99. & C. limnaei bengalensis & Naidu(1966) & Tibet \\
\hline 100. & C. orientalis & Naidu(1966) & Tibet \\
\hline 101. & C. pellucidus & Naidu(1966) & Tibet \\
\hline 102. & C. punjabensis & Naidu(1966) & Tibet \\
\hline 103. & C. spongilla & Naidu(1966) & Tibet \\
\hline 104. & C.cristallinus & Naidu and Naidu (1979) & Nilgiris (South India) \\
\hline 105. & Stylaria lacustris & Dhillon and Kaur (1991-96) & Patiala \\
\hline 106. & S. fossularis & Naidu and Naidu (1979) & Kashmir \\
\hline 107. & S. lacustris & Naidu and Naidu (1979) & Kashmir \\
\hline 108. & S. kempi & Naidu and Naidu (1979) & Kashmir \\
\hline 109. & S. fossularis & Naidu(1966) & Tibet \\
\hline 110. & S. kempi & Naidu(1966) & Tibet \\
\hline 111. & Slavina appendiculata & Naidu(1966) & Tibet \\
\hline 112. & S. Montana & Naidu(1966) & Tibet \\
\hline 113. & S. appendiculata & Naidu and Naidu (1979) & Nilgiris (South India) \\
\hline 114. & Haemonais laurentii & Naidu(1966) & Tibet \\
\hline 115. & H. waldvogeli & Naidu(1966) & Tibet \\
\hline 116. & Naidium breviseta & Naidu(1966) & Tibet \\
\hline 117. & N. jenkinae & Naidu(1966) & Tibet \\
\hline 118. & N. menoni & Naidu(1966) & Tibet \\
\hline 119. & N. minutum & Naidu(1966) & Tibet \\
\hline 120. & Bothrioneurum iris & Naidu et.al., (1979) & Andhra Pradesh (Vizianagaram) \\
\hline 121. & B. iris & Rani (1975) & Ludhiana \\
\hline
\end{tabular}


Table 1 contd....

\begin{tabular}{|c|c|c|c|}
\hline 122. & B. iris & Naidu(1966) & Tibet \\
\hline 123. & Branchiura sowerbyi & Naidu et.al., (1979) & Andhra Pradesh (Vizianagaram) \\
\hline 124. & B. sowerbyi & Sharma (1993) & Ludhiana \\
\hline 125. & B. sowerbyi & Naidu(1966) & Tibet \\
\hline 126. & Limnodrilus hoffmeisteri & Sharma (1993) & Patiala, Ludhiana \\
\hline 127. & L. socialis & Rani (1975) & Ludhiana \\
\hline 128. & L. hoffmeisteri & Naidu and Naidu (1979) & Kashmir \\
\hline 129. & L. socialis & Naidu and Naidu (1979) & Kashmir \\
\hline 130. & L. socialis & Naidu and Naidu (1979) & Nilgiris (South India) \\
\hline 131. & L. hoffmeisteri & Naidu and Naidu (1979) & Nilgiris (South India) \\
\hline 132. & L. hoffmeisteri & Naidu(1966) & Tibet \\
\hline 133. & L. socialis & Naidu(1966) & Tibet \\
\hline 134. & L. grandisetosus & Naidu(1966) & Tibet \\
\hline 135. & L. udekimianus & Naidu(1966) & Tibet \\
\hline 136. & Aulodrilus remex & Rani (1975) & Ludhiana \\
\hline 137. & A. kashi & Naidu(1966) & Tibet \\
\hline 138. & A. pectinatus & Naidu(1966) & Tibet \\
\hline 139. & A. pluriseta & Naidu(1966) & Tibet \\
\hline 140. & A. remex & Naidu(1966) & Tibet \\
\hline 141. & A. stephensoni & Naidu(1966) & Tibet \\
\hline 142. & A. trivandranus & Naidu(1966) & Tibet \\
\hline 143. & Tubifex tubifex & Dhillon and Kaur (1991-96) & Ferozepur \\
\hline 144. & T. tubifex & Naidu and Naidu (1979) & Kashmir \\
\hline 145. & T. tubifex & Naidu(1966) & Tibet \\
\hline 146. & T. blanchardi & Naidu(1966) & Tibet \\
\hline 147. & T. tubifex & Naidu and Naidu (1979) & Nilgiris (South India) \\
\hline
\end{tabular}

Bangalore, Kakinada, Bombay, Khed, Lahore, Dacca and Kashmir.Genus Dero was first reported by Oken (1815). It enjoys worldwide distribution in Europe, Asia, Africa, Australia, North and South America. In Indian subcontinent, this genus has been reported from Ceylon, Trivandrum, Ouralpatti, Tandikondi, Madras, Cuddapah, Bellary, Bangalore, Bombay, Lahore, Dacca and Kashmir. Genus Nais was first of all reported by Muller in 1773. It is distributed in Europe, Asia, North and South America. As far as distribution of this genus in Indian subcontinent, it is reported from Ceylon, Bheemnagar, Bangalore, Khandala, Kausali, Agra, Lahore, Kashmir, Yercaud and Afghanistan. Genus Allonais was first reported by Sperber (1948). It is distributed in Europe, Asia, Africa, North and South America. In Indian subcontinent, it is distributed in Ceylon, Cuddapah, Bellary and Kakinada.Genus Pristina Ehrenberg (1828) is reported from Asia, Europe, Africa, Australia, North and South America. In Indian sub-continent, presence of this parasite has been recorded from Ceylon, Bellary, Kashmir and Lahore.Genus Bothrioneurum Stolc (1888) is reported from Malaya, China, Brazil and Lake- Titiaca. In Indian sub-continent, presence of this annelid has been noted in Trivandrum, Kakinada, Kodaikanal, Cuddapah and Eastern Himalayas.Genus Branchiura Beddard (1892) also enjoys their distribution in Europe, Asia, Africa, Australia, North and South America. In Indian sub-continent, presence of this annelid is reported in states like Punjab, Peninsular India and U.P.

Genus Limnodrilus Claparede (1862) is reported from Eurasia, Africa, North and South America but this Oligochaete has been reported from only Tibet and Punjab.Genus Tubifex Lamarck (1816) is reported from Eurasia, Australia, North and South America. In Indian sub-continent, this has been reported from Punjab, Kashmir, Tibet, Nilgiris, Coonoor, Bangalore.Genus Branchiodrilus Michaelsen (1900) has been reported from Eurasia, North and South America. In Indian sub- 
continent, it has been reported from Punjab and Pakistan only.Genus Chaetogaster Bear (1827), this genus of Oligochaete has been reported from Europe, Asia, Africa, Australia and North America. In Indian sub-continent, presence of this genus is noticed in freshwater bodies of Punjab, Tibet, Bengal, Mumbai and Kashmir.Genus Slavina was first of all reported by Vejdovsky in 1883. It is distributed in Europe, Asia, Africa, Australia, North and South America. In Indian sub-continent, it has been reported in Ceylon, Nagercoil, Alipur, Bhimtal, Dacca and Lahore.

Genus Stylaria was first of all reported by Lamarck (1816). This genus is distributed in Asia, Africa and North America. In Indian sub-continent, it has been reported in Cuddapah, Calcutta, Bhimtal, Afghanistan, Lahore, Dacca and Kashmir.Genus Haemonais Bretscher, 1900 was reported from Europe, Asia, South America, Middle and Eastern North America. In Indian sub-continent, it has been reported from only Tibet.Genus Aulodrilus was first of all reported by Bretscher in 1899. This genus is distributed in Europe, Asia, North and South America. In Indian subcontinent, it has been reported in Ludhiana and Tibet.Genus Naidium Schmidt (1847) has been reported from Europe, Asia, South and North America. In Indian sub-continent, this oligochaete has been reported from only Tibet.

\section{ECOLOGY}

The diversity of habitats oligochaetes inhabit is immeasurable. Oligochaeta have successfully exploited virtually every habitable niche from submerged caves and the anaerobic sulfur-rich thiobiotic sediments off the coast of Florida to the ice fields of Alaska. Most aquatic oligochaetes are free-burrowing, deposit feeders, ingesting sediment. Some species, however, lack a mouth, anus and alimentary canal. This small group of phallodriline tubificids inhabit the thiobiotic marine sediments, existing off the metabolic by-products of subcuticular symbiotic bacteria.

Freshwater families can be more readily generalized with respect to their individual habitat preferences. Naididae are common in the sediments of streams, ponds and slow moving rivers. Although they coexist with Tubificidae, Naididae occur in highest concentrations where tubificid densities are low and are most commonly associated with aquatic vegetation and in the coarse sediments of fast flowing streams. Many species appear to be herbivorous, grazing on algae, diatoms and plant fragments. However, at least one genus, Chaetogaster, is carnivorous. Naididae are primarily freshwater inhabitants. Although many species can tolerate short periods of saline exposure. Tubificidae are commonly referred to as "sludge worms" because they often form dense mats or writhing balls in the very fine sediments associated with organically enriched waters. The explanation for the extremely high densities of tubificids in organically polluted situations may be correlated to an increase of food and living space created by the exclusion of competitors due to the occurrence of anaerobic conditions. Tubificids generally exist in fine sediments such as muds and silts, where they graze off the microflora associated with the sediment they ingest. They less frequently occur in association with naidids where aquatic vegetation is abundant, or in the stagnant water of ponds and pools with high algal concentrations.

\section{COLLECTION AND PREPARATION}

Many environmental investigations require collecting a large number of substrate samples in a very short time period with the organisms to be sorted from the debris and identified at a later time. The most common method of collecting sediment is with either a grab sampler (i.e., a Ponar or Ekman) or hand core. Epsom salts may be added to the sample for 15 to 30 minutes to narcotize the organisms. The sediment is then washed through a 0.5 $\mathrm{mm}$ or less screen. The residue is then fixed with a $10 \%$ formalin solution stained to facilitate separation of the worms from the sediment. After a minimum of 48 to 72 hours, the formalin is decanted and replaced with $70 \%$ ethyl or isopropyl alcohol. These samples may remain in this condition indefinitely, providing the alcohol level is periodically checked or evaporation. Sorting the worms from the residue is accomplished using a dissecting microscope.

If the purpose of the collection is strictly for finding of oligochaetes and quantification is not a factor, an alternate method may be employed: elutriation. For elutriation, a bucket is filled about one-third to one-half full with sediment. The sediment is passed through a $1 \mathrm{~cm}$ to $2 \mathrm{~cm}$ screen to remove the rocks, course gravel, detritus and vegetation. Water is added to the sediment and swirled to suspend the organisms, the supernatant is decanted into a $0.25 \mathrm{~mm}$ screen and the resulting organisms rinsed into an appropriately labelled container. The sediment should be elutriated an additional two or three time to ensure removal of majority of worms from the sediment.

The live worms are then sorted from the sediment within 12 hours and fixed in a $10 \%$ formalin solution for at least 48 to 72 hours, and transferred to $70 \%$ alcohol.

For routinely examining large collections, the fastest method is to mount the worms on microscope slides in Amman's lactophenol. This is a temporary medium composed of phenol (carbolic acid), lactic acid, glycerol and water in a ratio of 1:1:2:1. Two drops of mounting medium are placed on each slide. One to five worms (depending on their size) are arranged in a row within each drop, and a cover slip is placed over the worms. Placement of the worms in a single row with their heads 


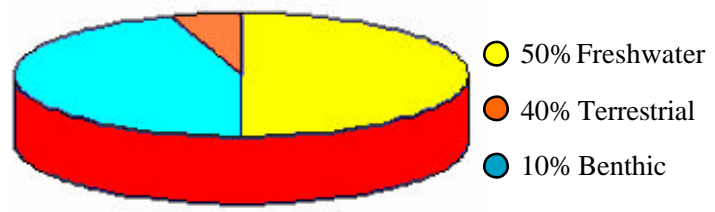

Fig.1. Showing distribution of Oligochaetes.

pointing in the same direction facilitates identification of large numbers of specimens simply by moving the stage left to right without having to look away from the microscope trying to locate each specimen. Tubificids may be fairly long and have a tendency to coil upon fixation, frequently obscuring taxonomically important characters. To straighten when mounting, grab one end with the forceps and drag it on the dry part of the slide into the drop of Amman's. This usually removes the kinks. The slides are placed on stackable slide trays, gluing thin spacers at $2.5 \mathrm{~cm}$ intervals to keep the slides separate. After each tray is mounted, examine the slides to ensure there are no air bubbles. If necessary, add a drop of mounting medium to edge of the cover slip. Capillary action will draw the fluid in to eliminate air spaces. Identification of freshwater material requires examination of setae and/or cuticular structures, such as penis sheaths. For this purpose, chemical maceration of the internal structures facilitates these observations. Gentle heating in drying oven set at approximately $90^{\circ} \mathrm{C}$, or on top of an electric range with burner control set at 3-1/4, for about 15 to 30 minutes, depending on the size of worms, hastens this process. Since temperature controls vary for each unit, experimentation and continuous examination of the specimens is initially required to prevent melting of worms, leaving only a scattered mass of setae.

If permanent mounts are required, Hydramount or CMC10 may be used. The specimens may be mounted directly into these media from water, alcohol or Amman's as described previously for temporary mounts. Both media will also clear the specimens after a day or two.

Identification of marine oligochaetes frequently requires the examination of internal structures. Generally, mount all specimens temporarily in Amman's lactophenol for preliminary examination. Specimens which need to be maintained for reference are carefully removed from the slide, stained in paracarmine stain, destained to the appropriate tint in acidified alcohol, dehydrated through an alcohol series, cleared in terpineol and mounted in Canada Balsam.

Dissection of the male genitalia of large specimens, such as Thalassodrilides is recommended for accurate identification. The dorsum of segments VII through XIII is torn open to expose the spermathecae and male genitalia. The lateral portions of the body wall are teased away, leaving only the ventral section containing the male

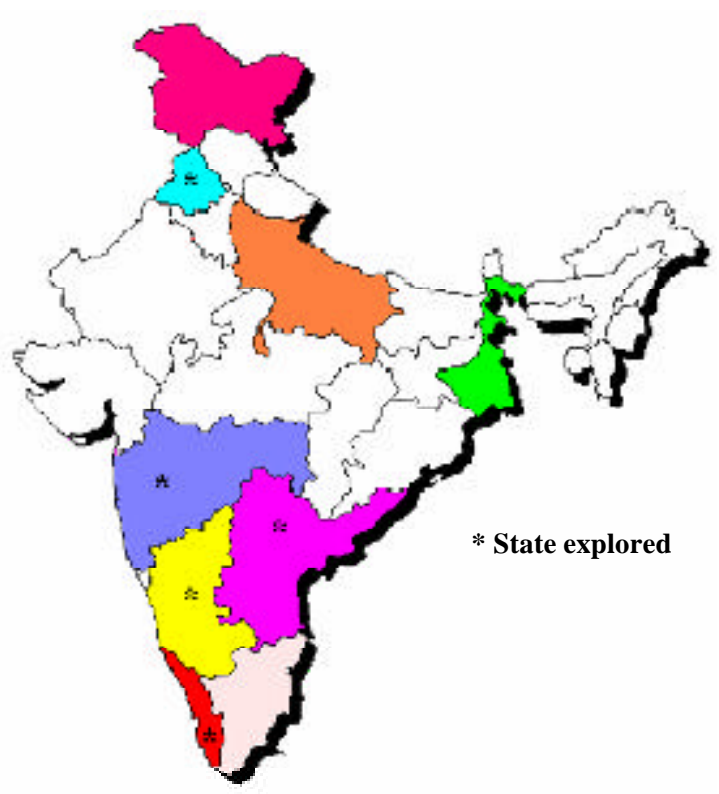

Fig.2. Map of India showing freshwater Oligochaetes.

and female pores and associated genital structures. Care may be taken to then remove the alimentary canal. The dissection may be accomplished in the final mounting medium or completed in alcohol, dehydrated and mounted in Canada balsam.

\section{MORPHOLOGY OF AN OLIGOCHAETE}

Oligochaetes are segmented, coelomate, bilaterally symmetrical, vermiform organisms. Aquatic oligochaetes are generally much smaller than their terrestrial counterparts. Usually they possess a sub terminal anterior mouth and a terminal anus. Each segment is separated by an "intersegmental groove" and designated by a roman numeral (Fig. 3.). The first segment (I) is the peristomium immediately posterior to the terminal prostomium which is produced into an elongate proboscis in some naidids and lumbriculids. Additionally, paired purple pigment spots (eyes) may be present in some species of naidids. This segment always lacks setae. Setae, generally first appear on segment II and are arranged in four discrete bundles, two dorso-lateral (dorsal bundles) and two ventro-lateral (ventral bundles). The dorsal bundles of setae of most naidids begin posterior to II. However, since this family reproduces primarily by asexual fission, with the anterior-most segments developing last, confusion frequently results when attempting to identify species based solely on setal placement.

The most obvious character useful in the identification of oligochaetes is setal morphology. Setae may be divided into two basic forms: hairs and crotchets (Fig. 4 and 5). 
Hairs are elongate, slender and terminate in a distally acute point, and lack a nodulus or intermediate swelling along the shaft. However, they may have lateral hairs or serrations occasionally appearing hispid. This type of setae is present only in dorsal bundles and occurs in the majority of Naididae, many of the Tubificidae and the Opistocystidae. Hairs are not present in Lumbriculidae and Enchytraeidae. These setae are characteristically stouter, have a characteristically sigmoid configuration and possess a nodulus, which is a swelling of the setal shaft at the point of emergence through the bodywall. Crotchets may be either bifid with an upper (distal) and lower (proximal) tooth, with or without intermediate teeth between the two main laterals, or they may be simplepointed. The crotchets of Naididae are usually more slender, with teeth not as robust as those of tubificids. The dorsal simple-pointed "crotchets" of naidids, which are frequently associated with hair setae, are referred to as needle setae, and may be minutely bifid.

Crotchets with intermediate teeth are called pectinate and in many species, can only be discerned at $1,000 \mathrm{x}$ magnification, although with experience pectinate setae may be determined at a lower power by the configuration of the lateral teeth. Pectinate setae are normally restricted to the dorsal bundles and are only found in tubificids and naidids. Except for a few species of Tubificidae in the genus Tubificoides, pectinate setae in marine taxa are rare. The anterior ventral bundles of some tubificids occasionally exhibit small intermediate teeth.

Modified ventral setae associated with genital pores occur in mature individuals of many taxa. These can be diagnostic characters for many species of Tubificidae, but are of incidental importance in species discrimination Naididae. The later family reproduces primarily asexually; mature individuals are infrequent.

In Tubificidae, modified setae associated with the spermathecal pore, usually on segment $X$, are called "spermathecal setae" and have a characteristic elongate spoon shape (Fig.5). As a general rule, there is only one seta per "bundle". Modified setae associated with the male pore, usually on segment XI, are referred to as "penial setae". These setae exhibit considerable interspecific variation, with generally more than one per bundle, and may be arranged in a fan-shaped configuration (Fig.5). Rarely do both spermathecal and penial setae occur in the same species.

The reproductive structures are the primary distinguishing characters among oligochaete taxa. Oligochaetes are hermaphrodites, possessing both fully developed male and female organs simultaneously within a single mature individual. Although self-fertilization has not definitively been demonstrated, parthenogenetic reproduction is suspected in a few taxa lacking spermathecae. Cross fertilization with the exchange of sperm between concopulants is generally the rule. A mucoid cocoon forms around the genital segments with the sperm from the concopulant and the eggs from the mate released into the cocoon, resulting in fertilization which is therefore considered to be external. Sperm may aggregate into structures formed by sperm "glued together" in some way (spermatozeugmata) or be randomly distributed within the spermathecae. The position of the spermathecal pores may be dorsal, ventral, lateral, anterior or posterior, single or paired, and is also species specific.

The morphology of the spermatheca and male genitalia are particularly significant in the identification of Tubificidae. The spermatheca is generally formed by an ectal vestibule, an intermediate spermathecal duct and an ental spermathecal ampulla where the sperm is stored. The male reproductive structures consist of an ental sperm funnel leading into a ciliated vas deferens, which empties into an atrium. The atrium customarily has a prostate gland associated with it. This gland may be diffusely attached to the atrium as in the Rhyacodrilinae, broadly attached as in the Limnodriloidinae, or attached by a short stalk as in the Tubificidae. Entally, the atrium may form an ejaculatory duct terminating simply as a pore, or forming a penis or pseudopenis which may be ensheathed in cuticle, the shape of which is highly diagnostic, particularly in the freshwater Limnodrilus and the marine Tubificoides. The cuticularized penis sheath is most easily distinguished in cleared specimens. The penis may be withdrawn into a copulatory sac, and it may have copulatory glands, as in Tectidrilus bori, associated with it. Although the male organs may be paired, they occasionally unite ectally or discharge through a common bursa. The male pores are always ventral or ventro-lateral in position in Tubificinae.

A modification of the gut in segment IX characterizes the subfamily Limnodriloidinae. This modification may be in the form of an enlarged gut with a distinct blood plexus or having two anterior projecting digitiform processes.

The final character having taxonomic significance with reference to this manual is the presence of coelomocytes. These are small to large nucleated cells which float free in the coelomic fluid. They are derived from the chlorogogen tissue associated with the alimentary canal, and are presumably aid in the distribution of nutrients throughout the body. Although they are present to some degree in all taxa, they are particularly abundant and conspicuous in most Rhyacodrilinae.

The present study concluded that the Indian freshwater oligochaete fauna is represented by following genera Aeolosoma, Aulophorus, Nais, Dero, Allonais, Pristina, Branchiodrilus, Chaetogaster, Stylaria, Slavina, Haemonais, Naidium, Bothrioneurum, Branchiura, Limnodrilus, Aulodrilus, Tubifex. These genera are 
distributed in four different families -Aeolosomatidae, Naididae, Tubificidae, Pristinidae. As besides being a fish food and a principle biotic component, freshwater oligochaetes use to act as intermediate host of Myxosporians which causes a serious parasitic problem for the freshwater fishes. Further, a thorough survey of various states is needed systematically, which will add to existing knowledge of freshwater Indian oligochaetes and will also help in understanding the life cycle of myxosporians infecting fishes.

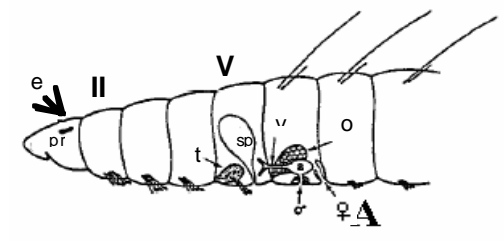

NAIDIDAE

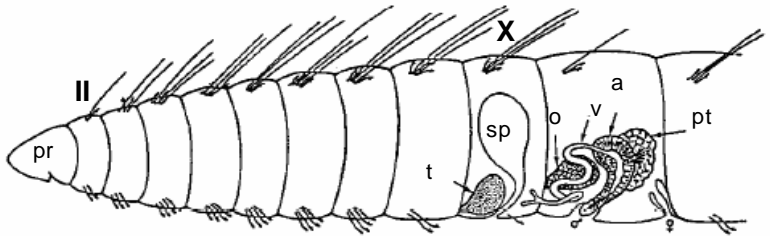

TUBIFICIDAE

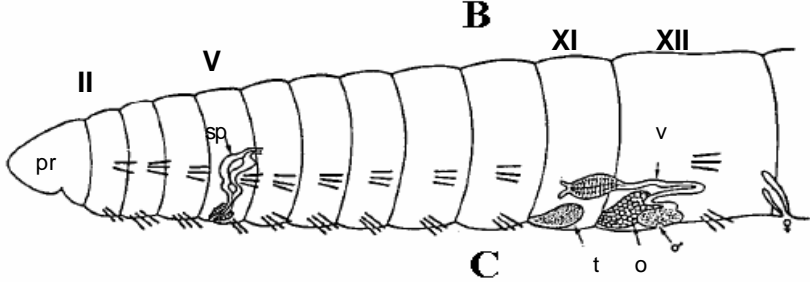

ENCHYTRAEIDAE

Fig.3. A typical Oligochaete (after Brinkhurst,1986) pr-Prostomium, e-Eye spot, sp-Spermatheca, t-Testis, o-Ovary, v-Vas deferens, a-Atrium, pt- Prostate, $\boldsymbol{\sigma}^{\top}$-Male genital pore, $\mathbf{9}-$-Female genital pore

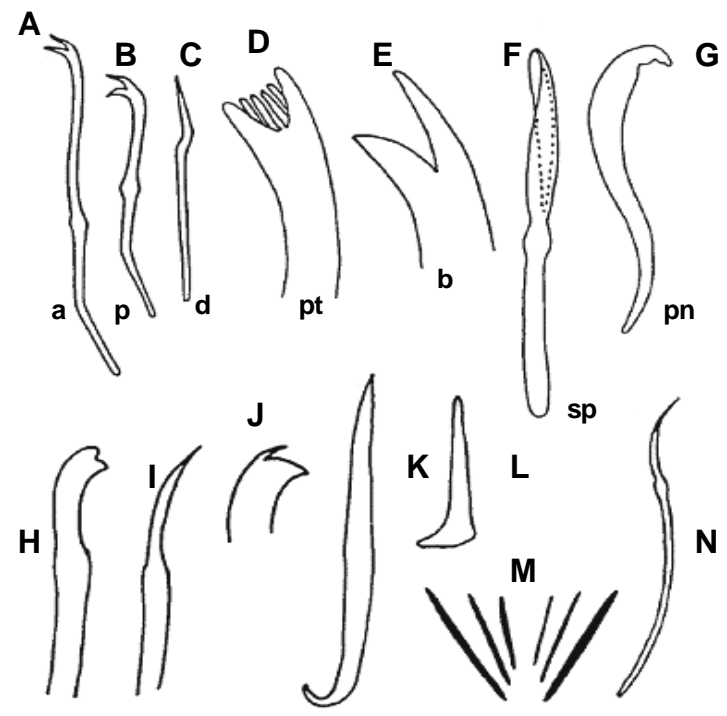

Fig.4. Oligochaete setae (after Brinkhurst,1982) A-C Naididae, D-G Tubificidae, H-J Lumbriculidae, K-N Enchytraeidae (KLumbricillus, L- Grania, M- Fridericia, N Cernosvitoviella) d-Dorsal,a-Anterior ventral,p-Posterior ventral,b-Bifid, ptPectinate,sp-Spermathecal, pn-Penials 


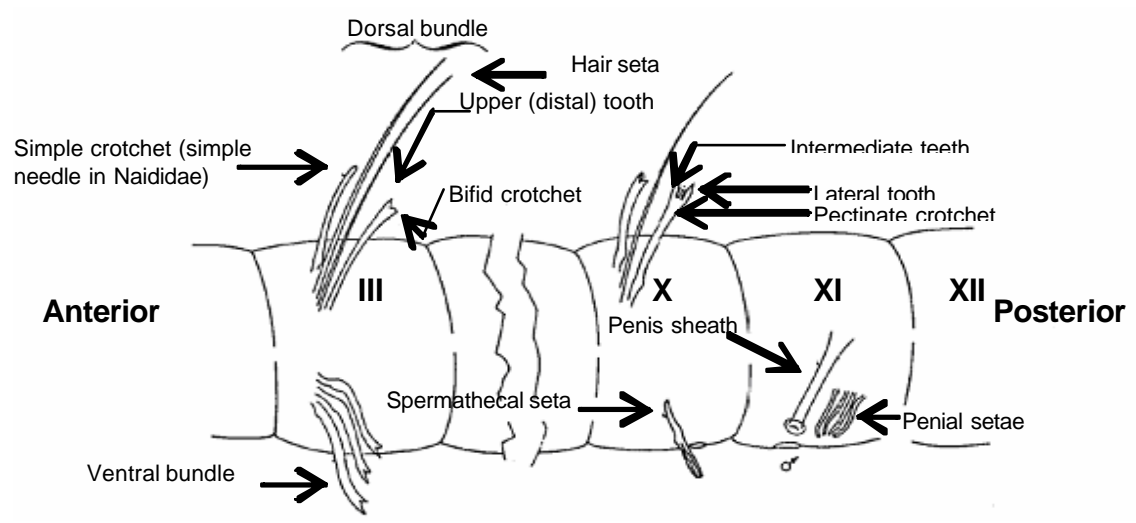

Fig.5. Generalized Tubificid (after Hiltunen and Klemm,1980).

\section{REFERENCES}

Bear, K. Von. (1827). Beitrage zur kenntnis der niedern Thiere III. Nova Acta Phys. Med. Acad.

Leop. Carol. Nat. Cur. Bohn. 13 : 605-615.

Beddard, F. E. (1892). On some aquatic oligochaetous worms. Pro. Zool. Soc. London. 349-361.

Bretscher, K. (1899). Beitrag zur Kenntniss der Oligochaeten fauna der Schweiz. Revue Suisse Zool. 6: 369-426.

Bretscher, K. (1900). Mitteilungen uber die Oligochaeten fauna der Schweiz. Revue Suisse Zool. 8: 1-44.

Brinkhurst, R.O. (1982). Evolution in the Annelida. Can. J. Zool. 60 : 1043-1059.

Brinkhurst, R.O. (1986). Guide to the freshwater aquatic microdrile oligochaetes of North America.Can. Spec. Publ. Fish. Aquat. Sci. 84. vi+259 pp.

Brinkhurst, R.O. and Jamieson, B. G. M. (1971). Aquatic Oligochaeta of the world. Oliver and Boyd, Edinburg, XI, $860 \mathrm{p}$.

Brinkhurst, R.O. and Wetzal, M. (1984). Aquatic Oligochaeta of the world : Supplement. Can. Tech. Rep. Hydrogr. Ocean Sci. $44: 1-101$.

Claparede, E. R. (1862). Recherches sur I'anatomie d'oligochaetes; Mem. Soc. Phys. Hist. Nat. Genev. 16: 217 291.

Dhillon, S. S., and Kaur, H. (1991-1996). Analytical studies on aquatic ecosystem of Punjab- Final Technical Report.

Ehrenburg, Ch.G. (1828). Symbolae pysicae- Animalia evertebrata. Decas 1. Phytozoa, Berolini, P. 1- 293.

Kalpana, K. and Naidu, K.V. (1979). Aulophorusflabelliger Stephenson, 1931, A rare and interesting freshwater oligochaete new to Asia.Hydrobiologia vol. 67: 273-274.

Lamarck, J. B. (1816). Histoire naturelle des animaux sans vertebras. 3. Paris.

Michaelsen, W. (1900). Das Tierreich 10 : Vermes, Oligochaeta. Friedlander and Sohn, Berlin. Pp. xxix+ 575.

Muller, O. F. (1773). Vermium terrestrium et fluvitalium seu Infusoriorum Helminthicorum et Testaceorum non marinorum succincta historia. Helminthica. Havniae et Lipsiae ; 1-214.

Naidu, K. V. (1966). Check-list of Fresh-water Oligochaeta of the Indian sub-continent and Tibet. Hydrobiologia 27 : 208226.

Naidu, K.V., Kalpana , K. and Suresh Kumar, K. (1979). Aquatic Oligochaeta from among the roots of Eichhornia crassipes Solms, Hydrobiologia . 76: 103-112.

Naidu, K.V. and Naidu, K. A. (1979). Some freshwater Oligochaeta from Kashmir, India. Proc. Indian Acad. Sci., Vol. Part I. 6 : 411-419.

Naidu, K.V. and Naidu, K. (1979). Some aquatic Oligochaetes of the Nilgiris, South India. Hydrobiologia . 76:113-118.

Oken, L. (1815). Lehrbuch der Naturgeschichte 3 : Zoologie 1 : Oligochaeta . Leipzig. 313-363.

Rani, R. (1975). "Survey of oligochaete Fauna of Punjab”. M.Sc. Disseration,(Supervisor V. C. Kapoor) Deptt. Of Zoology, PAU., Ludhiana.

Schmarda, L. (1861). Neue Wirbellose Tiere, Oligochaeta . Leipzig. $1: 7-17,54-56$.

Sharma, M. (1993). "Taxonomic studies on the macrobenthos from Punjab waters, Ph.D. thesis ; (Supervisor : S. K. Battish) Deptt. Of Zoology, PAU., Ludhiana.

Stolc, A. (1888). Monographie ceskych Tubificida. Sker. K. Bohm. Ges. Wiss., VII. 2 : 1-43.

Sperber, C. (1948). A taxonomical study of the Naididae.Zool. Bidr. Uppsala. 28: 296.

Stephenson, J. (1930). The Oligochaeta. Oxford. xvi+978 p.

Vejdovsky, R. (1883). Revisio Oligochetorum Bohemiae. Sitz. Ber. Bohm. Ges. Wissensch. Prag. 1883: 215-228.

* Some old references are not cited 